\title{
Vysokoteplotní fázové transformace kaolinitu v závislosti na krystalinitě
}

\author{
Effect of crystallinity on high-temperature phase transitions of kaolinite
}

\section{Petr Štursa' $\leftrightarrows$, , Dalibor Všianský1, Karel Lang², Lenka Nevřivová3 , Lukáš Tvrdík², Pavel Kovář́, Lucie Keršnerová}

' Ústav geologických věd, Prírodovědecká fakulta, Masarykova univerzita, Kotlářská 267/2, 61137 Brno

${ }^{2} P$-D Refractories CZ a.s., Nádražní 218, 67963 Velké Opatovice

${ }^{3}$ Ústav technologie stavebních hmot a dílců VUT v Brně, Fakulta stavební, Veveří 95, 60200 Brno

Key words:

Kaolinite, crystallinity, Hinckley index, X-ray diffraction, thermal analysis

$\square$ petr.stursa@hotmail.cz

Editor:

Zdeněk Losos

\begin{abstract}
Although kaolinite is one the most important industrial minerals, the processes of its transformation to mullite have not been completely explained so far. The study is focused on kaolinite crystallinity calculation and its effect on high-temperature phases transitions in the series kaolinite-mullite. Samples of purified natural kaolins from several sites were analysed using X-ray diffraction (XRD). Besides the determination of the complex mineral composition, kaolinite crystallite size was calculated from XRD data by the Rietveld method, Scherrer equation and using the Hinckley crystallinity index. Thermal analysis (DSC/TG) was used as the principal approach to examine endothermic and exothermic effects of kaolinite transformations. The course and maximum temperatures of the observed effects were correlated with the original crystallite size of kaolinite. Two samples with different kaolinite crystallinity were also analysed by high-temperature $X$-ray diffraction (ht-XRD) to study the formation of mullite. Scanning electron microscope (SEM) was used to visualize morphology of kaolinite.

It was found out that the original crystallinity of kaolinite affects all three examined processes - kaolinite dehydroxylation, formation of crystalline phases from metakaolinite and development of mullite crystal structure. Dehydroxylation of samples with higher kaolinite crystallinity takes place at higher temperatures. Similar effect applies for the reaction(-s) at the temperature about $980^{\circ} \mathrm{C}$ observed at heat flow curve where crystallization of spinel type phase and mullite with very low crystallinity occurs. Broadening of FWHM of the exothermic effect points to decreasing kaolinite crystallinity. Crystallization of mullite exhibits different dependence on kaolinite crystallinity than the previous processes. The results show that mullite with larger crystallite size develops faster from kaolinite of low crystallinity and vice versa.
\end{abstract}

\section{Doporučená citace článku:} Štursa, P., Všianský, D., Lang, K., Nevřivová, L., Tvrdík, L., Kovářr, P., Keršnerová, L. (2020). Vysokoteplotní fázové transformace kaolinitu v závislosti na krystalinitě. Geologické výzkumy na Moravě a ve Slezsku, 27, 1-2, 21-26.

DOI: https://doi.org/10.5817/ GVMS2020-12674

\section{Úvod}

Kaolinit je jedním z nejdůležitějších minerálů pro keramický průmysl a zároveň je chemicky i strukturně jeden z nejjednodušších jílových minerálů. Přesto průběh jeho fázových transformací při výpalu dosud nebyl zcela uspokojivě objasněn. Jedná se především o vznik krystalických fází z metakaolinitu, na jejichž průběh se názory v historické i současné literatuře rozcházejí (Brindley, Nakahira 1959a, b, c; Lee et al. 1999; Chakraborty 2014).

Kaolinit je triklinický minerál ze skupiny fylosilikátů. Stechiometricky lze jeho složení vyjádřit vzorcem $\mathrm{Al}_{2} \mathrm{Si}_{2} \mathrm{O}_{5}(\mathrm{OH})_{4}$ a pomocí oxidů jako 46,64\% $\mathrm{SiO}_{2}, 39,60 \% \mathrm{Al}_{2} \mathrm{O}_{3}$ a 13,96\% $\mathrm{H}_{2} \mathrm{O}$ (Č́́ćcel et al. 1981; Murray 2006). Vrstvy typu $1: 1$ jsou složeny $\mathrm{z}$ tetraedrické $\left(\mathrm{SiO}_{4}\right)$ a dioktaedrické $\left(\left[\mathrm{Al}_{2}(\mathrm{OH})_{4}\right]^{2}\right)$ sítě 
s pseudohexagonální symetrií (Lee et al. 2003). Vzniká převážně hydrotermální alterací alkalických živců pocházejících z granitů. Kaolinit je obecně nejvíce zastoupeným minerálem kaolinu, jedné ze základních surovin keramických materiálů. Jedná se o nezpevněnou sedimentární horninu, která kromě kaolinitu může obsahovat další jílové minerály, především illit, montmorillonit nebo dickit, slídy, anatas, živce a další minerály (Varga 2007). Před použitím v keramickém průmyslu je kaolin upravován. Ve srovnání s přírodním stavem dochází tzv. plavením k výraznému zvýšení poměru kaolinitu a doprovodných minerálů.

Při výpalu dochází u kaolinitu k několika následujícím fázovým transformacím. Při teplotě kolem $450{ }^{\circ} \mathrm{C}$ začíná probíhat dehydroxylace. Uvolněním $(\mathrm{OH})^{-}$skupin ze struktury kaolinitu vzniká rentgenoamorfní fáze, metakaolinit. Z metakaolinitu následně vzniká tzv. spinelová fáze okolo teploty $980{ }^{\circ} \mathrm{C}$ a zároveň začíná krystalizace mullitu $2: 1\left(2 \mathrm{Al}_{2} \mathrm{O}_{3}: 1 \mathrm{SiO}_{2}\right)$ o velmi nízké krystalinitě. Zvyšování obsahu obsahu mullitu se výrazně zrychluje při teplotě okolo $1200^{\circ} \mathrm{C}$ a zároveň se chemické složení mullitu postupně mění z $2: 1$ na $3: 2$. Část $\mathrm{SiO}_{2}$ z metakaolinitu zůstává $\mathrm{v}$ amorfní podobě a při teplotě nad $1200^{\circ} \mathrm{C}$ z něj krystalizuje cristobalit (Brindley, Nakahira 1959c; Lee et al. 1999; Chakraborty 2014).

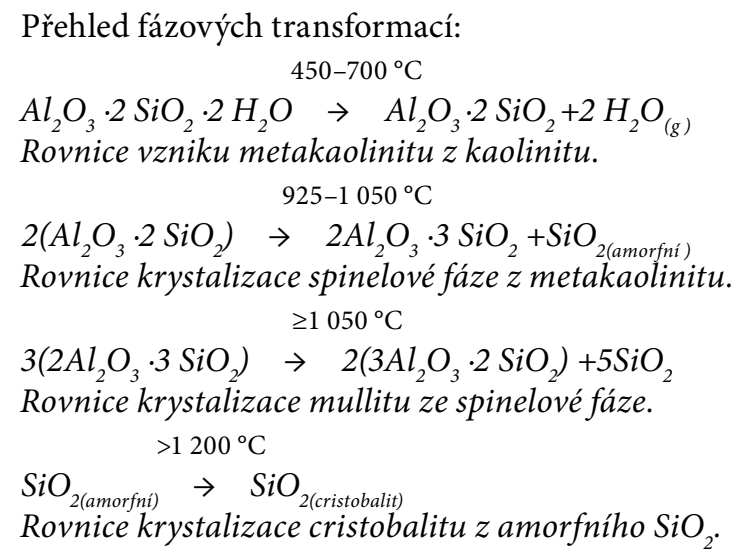

Kaolinit $\mathrm{z}$ různých lokalit se může lišit morfologií krystalů a jejich agregátů, kterou lze pozorovat pomocí skenovací elektronové mikroskopie. Zároveň se může lišit krystalinitou ve smyslu velikosti koherentních domén krystalové struktury neboli krystalitů. Výraz krystalinita se často také používá pro vyjádření obsahu amorfní fáze ve vzorku. Nejběžnějším nástrojem stanovení velikostí krystalitů je prášková rtg-difraktometrie. Předmětem této studie je posouzení vlivu průměrné velikosti krystalitů kaolinitu na průběh výše uvedených fázových transformací. Krystalinita kaolinitu jako technologicky potenciálně důležitá vlastnost byla dosud zkoumána pouze sporadicky (Belloto et al. 1995), ucelená studie na toto téma zatím chybí.

\section{Materiál a metodika}

Studováno bylo osm vzorků plavených kaolinů označených 18862, Al, DS1, GP3, KE, K, KN-83 a ZREF, které dodala firma P-D Refractories CZ, a.s. Lokality,
Tab. 1: Přehled studovaných kaolinů a jejich lokalit.

Tab. 1: Overview of examined kaolins and their localities.

\begin{tabular}{|c|c|}
\hline Kaolin & Lokalita \\
\hline 18862 & Božíčany \\
\hline DS1 & Chlumčany \\
\hline GP3 & Kazatin-Ukrajina \\
\hline KN-83 (=ZREF) & Kazatin-Ukrajina \\
\hline $\mathrm{Al}$ & Francie $^{*}$ ) \\
\hline $\mathrm{KE}$ & Francie $^{\star}$ ) \\
\hline $\mathrm{K}$ & Francie $^{\star}$ ) \\
\hline
\end{tabular}

*) Tyto vzorky dodala firma SOKA (Société kaolinière armoricaine).

Přesná lokalizace jejich pưvodu je předmètem utajení.

ze kterých pocházejí jednotlivé kaoliny, jsou zobrazeny v tabulce 1 .

Práškové preparáty byly připraveny pomocí laboratorního mlýnku McCrone Micronising Mill. Jako mlecí médium byl použit isopropylalkohol. Všechny vzorky byly analyzovány rentgenovou práškovou difrakcí (XRD) a termickou analýzou (diferenční skenovací kalorimetrie a termogravimetrie, DSC/TG).

XRD analýzy byly provedeny na přístroji Panalytical Empyrean $\mathrm{s} C u$ anodou $(\lambda=1,5406 \mathrm{~nm})$ a pozičně citlivým detektorem při konvenční $\theta-\theta$ reflexní geometrii. Parametry měření: $45 \mathrm{kV}, 40 \mathrm{~mA}$, úhlový rozsah: $5-80^{\circ} 2 \theta$, krok $0,013^{\circ} 2 \theta$, čas na krok 157 s. Celkový čas měření jednoho skenu dosahoval cca 60 min. Kvantitativní fázová analýza byla provedena pomocí Rietveldovy metody v software HighScore 3 Plus. Pro vyhodnocení byla zvolena krystalografická databáze ICSD-Inorganic crystal structure database 2012. Použité referenční vzory pro vyhodnocení: kaolinit (98-008-0082), illit (98-009-0144), křemen (98-000-0174), anatas (98-0009853), K-živec (98-008-8896), muskovit (98-007-9027). Krystalinita kaolinitu byla na základě difrakčních dat stanovena třemi metodami: pomocí Hinckleyho indexu krystalinity (Hinckley 1962), Rietveldovou metodou (Rietveld 1969) a pomocí Scherrerovy rovnice (Scherrer 1918) včetně Warrenovy korekce.

Dva vybrané vzorky s výrazně odlišnou krystalinitou kaolinitu, KN-83 a K, byly podrobeny in-situ vysokoteplotnímu XRD experimentu. Po nanesení na platinový filament byly práškové vzorky studovány pomocí vysokoteplotní komory Anton Paar HTK 2000 a výše popsaného rtg-difraktometru v teplotním rozsahu 960-1 $300^{\circ} \mathrm{C}$. Vlastní měření probíhala během izotermních výdrží v krocích po $10^{\circ} \mathrm{C}$. Úhlový rozsah: $32-36^{\circ} 2 \theta$, krok: $0,053^{\circ} 2 \theta$, čas na krok: $149 \mathrm{~s}$. U obou experimentů byl změřen i výchozí a konečný stav při $25^{\circ} \mathrm{C}$.

DSC/TG analýza byla provedena na př́stroji Setaram Setsys EVO 1750. Použity byly platinové kelímky. Vzorky byly zahřívány do teploty $1400^{\circ} \mathrm{C}$ s gradientem $10^{\circ} \mathrm{C} / \mathrm{min}$. Získaná data byla vyhodnocena pomocí programu Setaram Processing. U studovaných efektů byly z termogramů odečítány teploty počátku, konce, pološíŕky (FWHM) a maxima. Z důvodů subjektivity stanovení teplot počátku a konce efektu byly pro charakterizaci průběhu studovaných dějů použity především hodnoty 
onset a offset (průsečíky tečen $\mathrm{v}$ inflexních bodech s pozadím termogramu).

Po pokovení zlatem byla morfologie vzorků kaolinů vizualizována skenovací elektronovou mikroskopií (SEM) v režimu sekundárních elektronů pomocí přístroje TESCAN MIRA3. Urychlovací napětí: $20 \mathrm{kV}$.

\section{Výsledky}

\section{RTG - difrakční fázová analýza kaolinů}

Ve všech studovaných vzorcích kaolinů výrazně převažuje kaolinit. V pěti z osmi vzorků obsah tohoto minerálu přesahuje $90 \mathrm{hm}$. \%, nejvyšší obsah $(98 \mathrm{hm}$. \%) byl identifikován ve vzorku ZREF. Naopak nejnižší množství kaolinitu je př́tomno ve vzorku DS1 (76,8 hm. \%). Výrazně nižší je zastoupení illitu, křemene a anatasu. Ve vzorku DS1 byl identifikován alkalický živec v obsahu 7,5 hm. \%. Grafické znázornění výsledků XRD kvantitativní fázové analýzy - viz obrázek 1, stanovené obsahy - viz Elektronická př́loha 1 .

Ve vzorku KE jsou přítomny dva minerály se slídovou strukturou. Vedle illitu se s největší pravděpodobností jedná o muskovit. Spolehlivá oddělená kvantifikace illitu

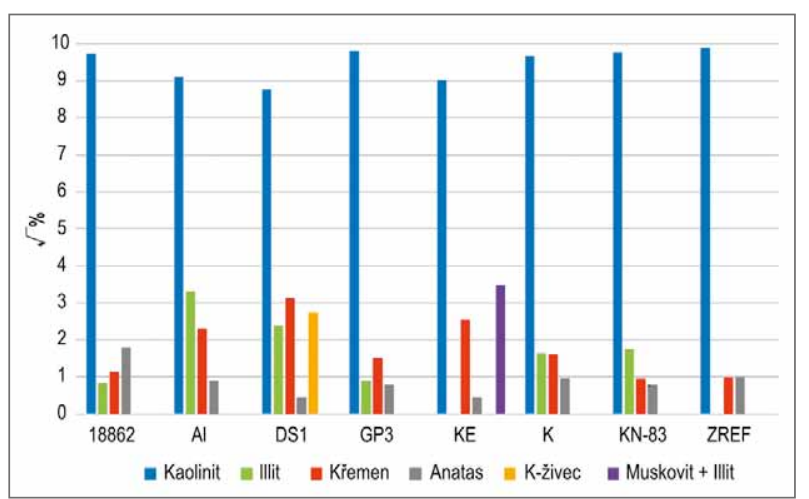

Obr. 1: Fázové složení studovaných vzorků kaolinů. Na ose y je hodnota druhé odmocniny stanoveného obsahu [hm. \%].

Fig. 1: Phase composition of studied kaolin samples. Y-axis shows the value of the square root of the determined content [wt. \%].

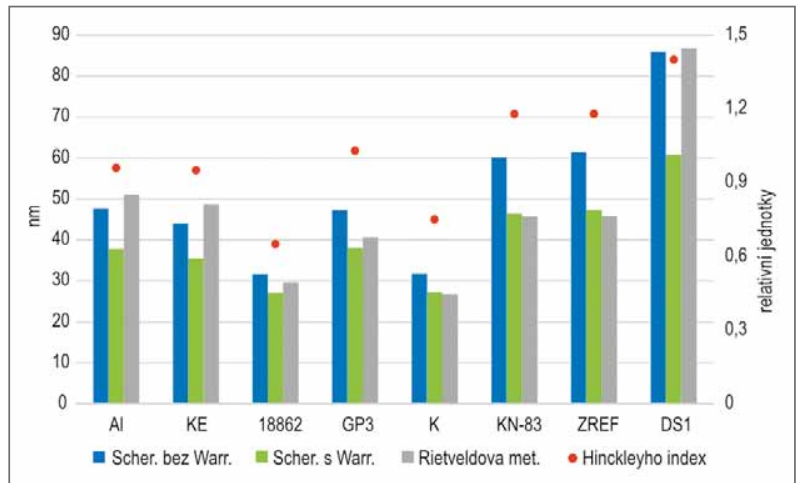

Obr. 2: Stanovení velikosti krystalitů kaolinitu v nanometrech pomocí Scherrerovy rovnice a Rietveldovy metody (znázorněno histogramem) a jako relativní hodnoty Hinckleyho indexu krystalinity (CI, znázorněno červenými body).

Fig. 2: Determination of kaolinite crystallite size in nanometres (Scherrer and Rietveld method) and as the relative value of the Hinckley crystallinity index (CI, shown by red dots). a muskovitu je vzhledem $\mathrm{k}$ jejich strukturní podobnosti obtížná, proto byly kvantifikovány jako suma obou těchto minerálů. Jejich obsah ve vzorku KE dosahuje 12,2 hm. \%.

$\mathrm{V}$ rámci studovaného souboru vzorků nebyl illit, respektive slídové minerály, identifikován pouze ve vzorku ZREF.

\section{Stanovení krystalinity kaolinitu}

Velikosti krystalitů kaolinitu se ve studovaných vzorcích navzájem výrazně liší. Nejvyšší krystalinita kaolinitu byla stanovena ve vzorku DS1. Relativně vysokých hodnot dosahuje i ve vzorcích KN-83 a ZREF. Následují pak vzorky Al, GP3 a KE. Nejnižší krystalinita kaolinitu byla stanovena ve vzorcích 18862 a K. Na obrázku 2 je graficky znázorněno srovnání výsledků získaných pomocí absolutních metod stanovení velikosti krystalitů (Scherrerova rovnice a Rietevldova metoda) a jedné metody relativní (Hinckleyho index krystalinity), vypočtené hodnoty - viz Elektronická prŕloha 1.

\section{Vysokoteplotní RTG-difrakce}

Touto metodou byl studován proces krystalizace mullitu v závislosti na krystalinitě kaolinitu v surovině. Byly sledovány nekoincidující difrakční linie mullitu (220) a (111). Ve vzorku K byla difrakční linie (111) zaznamenána až od teploty $1170^{\circ} \mathrm{C}$. Od teploty cca $1200^{\circ} \mathrm{C}$ nastal u obou vzorků výrazný nárůst obsahu mullitu. Rapidnější změnu rychlosti zvyšování obsahu mullitu lze kolem této teploty pozorovat u kaolinu K, který vykazoval nízkou krystalinitu kaolinitu. Ve srovnání s tímto vzorkem má kaolin KN-83 zřetelně pomalejší nárůst obsahu mullitu vlivem vyšší původní krystalinity kaolinitu (obr. 3).

Dále byla na základě porovnání pološířek (FWHW) difrakčních linií srovnána krystalinita vznikajícího mullitu. Ve vzorku s nižší krystalinitou kaolinitu byla krystalinita mullitu ve sledované teplotní oblasti (do $1300^{\circ} \mathrm{C}$ ) zřetelně vyšší (Elektronická příloha 3 ).

\section{Termická analýza}

Ztráta žíháním v rozmezí $40-1400{ }^{\circ} \mathrm{C}$ dosahuje 10,7\% (DS1) - 14,6\% (ZREF). Většina úbytku hmotnosti připadá na dehydroxylaci kaolinitu a pohybuje se v rozmezí 9,3\% (DS1) -12,6\% (ZREF). Teplota onset, offset a maxima a endotermního efektu př́slušejícího dehydroxylaci kaolinitu se u všech vzorků navzájem liší. Nejnižší onset teploty dehydroxylace se objevují u vzorků DS1 $\left(458,7^{\circ} \mathrm{C}\right), \operatorname{KE}\left(459,9^{\circ} \mathrm{C}\right)$ a $\mathrm{AL}\left(460,8^{\circ} \mathrm{C}\right)$. Tabulka $\mathrm{s}$ hodnotami odečtenými z termogramů - viz Elektronická př́loha 2. Dehydroxylace illitu je výrazně patrná pouze na křivce tepelného toku (heat flow) vzorku DS1. U ostatních kaolinů nebyl efekt dehydroxylace illitu pozorovatelný, pravděpodobně $z$ důvodu překrytí výraznějším efektem-dehydroxylací kaolinitu. Dalším výrazným efektem je až exoterma odpovídající vzniku krystalické (krystalických) fáze(-í) z metakaolinitu. Teploty tohoto efektu se, stejně jako u dehydroxylace, u všech vzorků navzájem liší. Počátek exotermního efektu je nejnižší u vzorku K s onset teplotou $974{ }^{\circ} \mathrm{C}$ a nejvyšší u vzorku KN-83 s teplotou onset $997,6^{\circ} \mathrm{C}$ (obr. 4). U vzorku GP3 v oblasti 


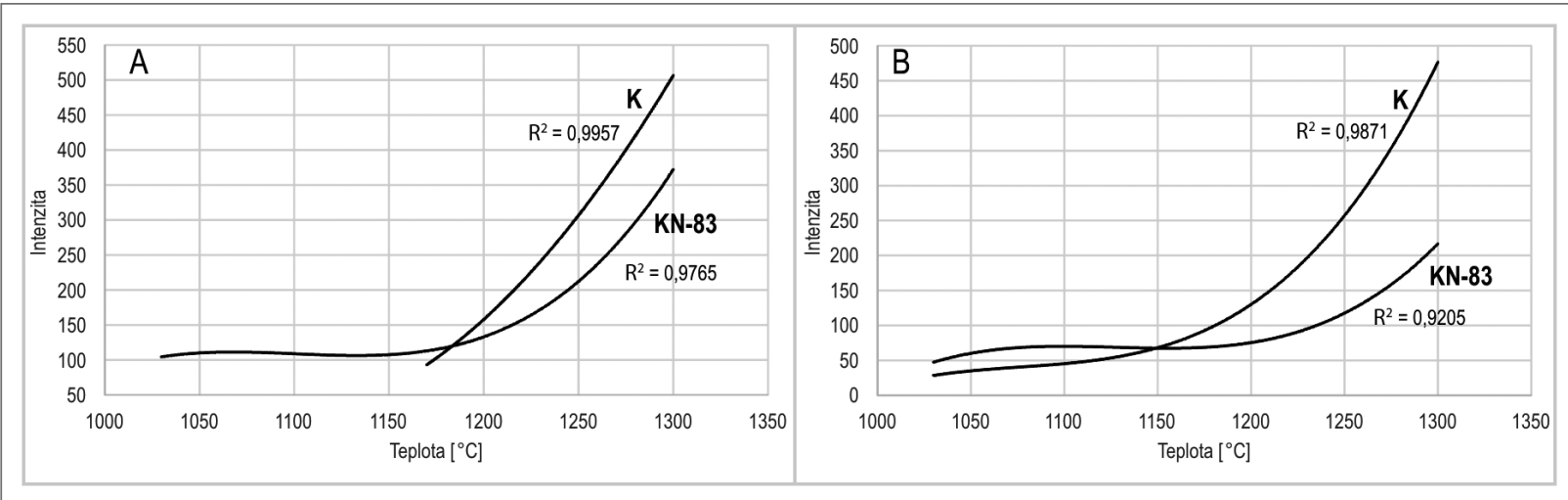

Obr. 3: Relativní změna obsahu mullitu při vysokotoplotním in-situ XRD experimentu ve vzorcích K a KN-83 pozorovaná na integrální intenzitě difrakční linie A) (1 111$)$ a B) (2 20). Získaná data byla proložena polynomickou funkcí druhého až třetího řádu. Fig. 3: The relative change of mullite content during the high-temperature in-situ XRD experiment in samples K and KN-83 observed on the integral intensity of the diffraction lines A) (111) and B) (220). Obtained data were interleaved by polynomial function of second to third order.

exotermního efektu jsou na heatflow křivce patrné dva vrcholy. Jednotlivé hodnoty získané $\mathrm{z}$ termické analýzy (heat, onset, offset, $\Delta \mathrm{m}$, maximum) jsou v elektronické príloze 2 ve formě tabulky.

Průběh vysokoteplotních fázových transformací kaolinitu v jednotlivých vzorcích byl srovnán s jeho krystalinitou. Korelace krystalinity kaolinitu vyjádřené pomocí Hinckleyho indexu krystalinity a průběhu dehydroxylaci a krystalizace tzv. spinelové fáze $\mathrm{z}$ metakaolinitu je znázorněna na obrázku 5 . Ostatní metody stanovení krystalinity (Rietveldova metoda, Scherrerova rovnice) nebyly ve vyhodnocení použity, jelikož nevykazovaly tak vysokou závislost, jako stanovení pomocí Hinckleyho indexu (další zdůvodnění - viz Diskuze).

\section{Diskuze}

Základní metodou studia průběhu fázových transformací byla termická analýza (DSC/TG). Při teplotě cca $100^{\circ} \mathrm{C}$ je na HF křivce pozorovatelný slabý endotermický efekt způsobený uvolněním adsorbované vody (např. Varga 2007). Vzhledem k použití termočlánku typu S jsou měření při takto nízkých teplotách značně nepřesná. Ztráta žíháním v průběhu celého experimentu se pohybuje od $10,7 \mathrm{hm}$. \% do $14,6 \mathrm{hm}$. \% a nejvyšší podíl na ztrátě hmotnosti má dehydroxylace kaolinitu. Hodnoty úbytku hmotnosti spojené s dehydroxylací kaolinitu (v teplotním rozmezí cca $430-640^{\circ} \mathrm{C}$ ) se pohybují od $9,3 \mathrm{hm}$. \% (vz. DS1) do 12,6 hm. \% (vz. ZREF). Pro srovnání lze uvést, že celková ztráta hmotnosti u čistého kaolinitu je 13,96 hm. \% (Murray 2006). Jedná se tedy převážně o velmi čisté kaoliny, čemuž odpovídá i obsah kaolinitu stanovený pomocí XRD.

$\mathrm{Na}$ křivce tepelného toku byly detailně sledovány efekty dehydroxylace a vzniku tzv. short-range order struktury metakaolinitu a krystalizace spinelové fáze a mullitu. U většiny vzorků lze pozorovat závislost průběhu obou těchto dějů na původní krystalinitě kaolinitu. Vzorky s nižší krystalinitou ve většině př́ípadů vykazují posun počátků i maxim obou sledovaných efektů do oblasti nižších teplot. Tento jev je velmi výrazný u vzorků 18862 a K se slabě krystalickým kaolinitem, kde hodnoty maxima těchto efektů dosahují 534,9 a $533,5^{\circ} \mathrm{C}$

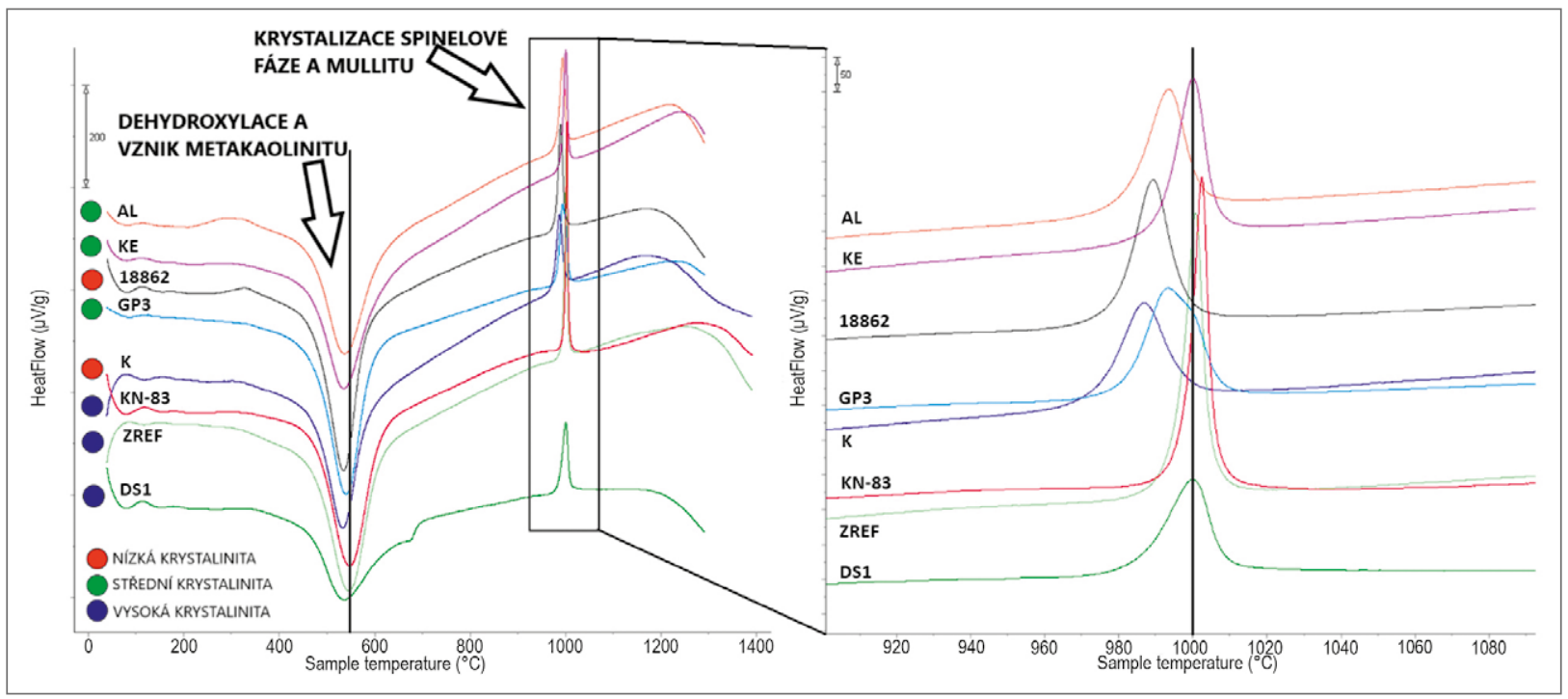

Obr. 4: Kř̌ivky tepelného toku (heat flow). Pro snadnější orientaci vertikální úsečky označují teploty 550 a $1000^{\circ} \mathrm{C}$.

Fig. 4: Heat flow curves. For easier orientation, vertical bars indicate temperatures of 550 and $1000^{\circ} \mathrm{C}$. 


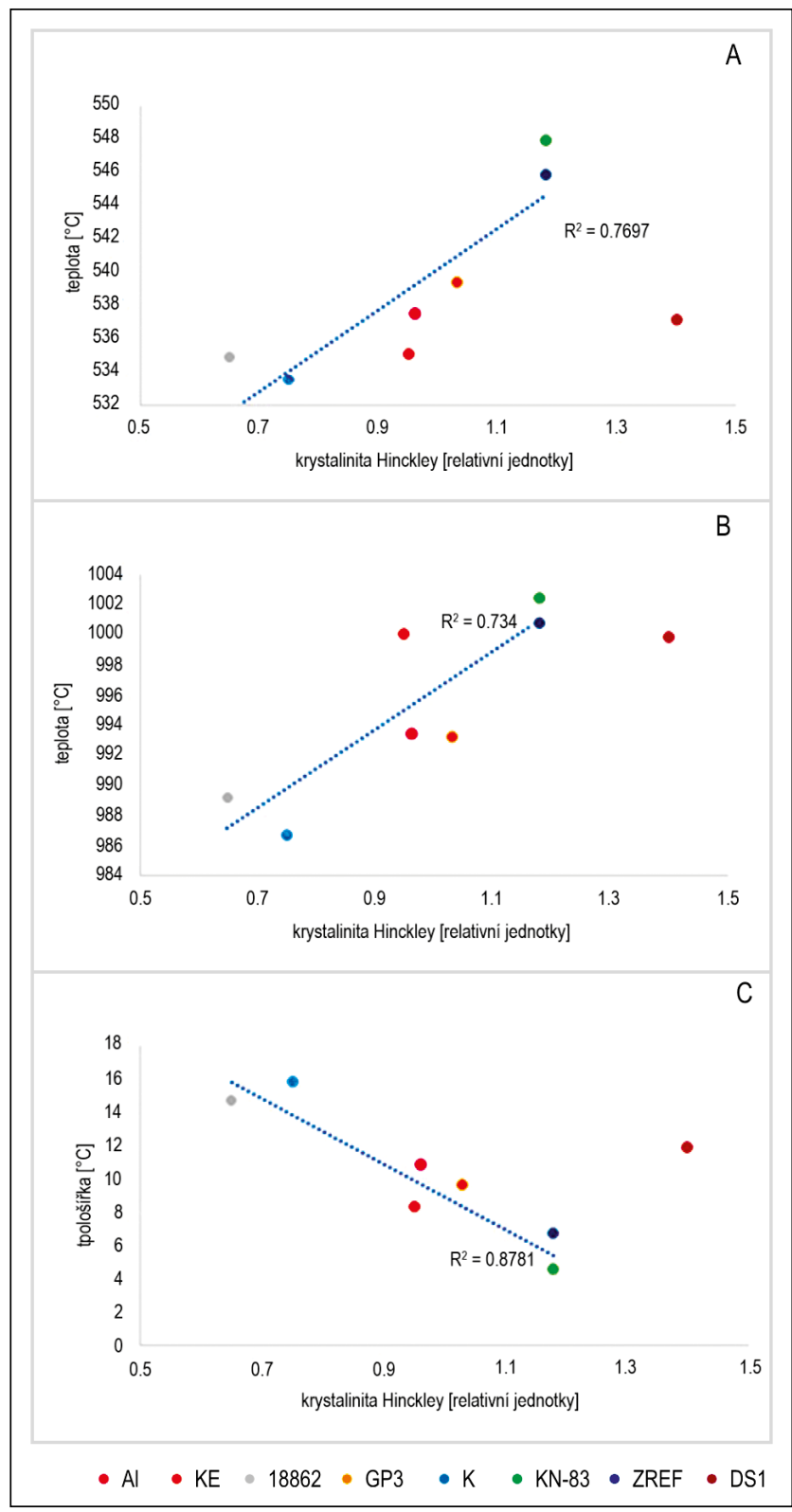

Obr. 5: Závislost hodnoty Hinckleyho indexu na: A) teplotě maxima dehydroxylace; $B$ ) teplotě maxima krystalizace spinelové fáze a mullitu; C) pološíŕce exotermního píku krystalizace spinelové fáze a mullitu. $Z$ regrese byl vynechán vzorek DS1.

Fig. 5: Correlation of Hinckley index value with: A) maximum dehydroxylation temperature; B) maximum crystallization temperature of spinel phase and mullite; C) FWHM (half-width) of the exothermic peak of spinel phase and mullite crystallization. DS1 was omitted from the regression.

(dehydroxylace) a 989,1 a $986,7^{\circ} \mathrm{C}$ (krystalizace z metakaolinitu). Naopak u vzorků s vysokou krystalinitou kaolinitu KN-83 a ZREF tyto hodnoty dosahují 547,7 a $545,9^{\circ} \mathrm{C}$ a 1002,4 a $1000,75^{\circ} \mathrm{C}$. Tyto výsledky jsou v souladu s publikací Belloto et al. (1995). Regresní prímky potvrzují závislost probíhajících vysokoteplotních procesů na původní krystalinitě kaolinitu. Koeficienty determinace $\mathrm{R}^{2}$ dosahovaly u maxim endotermy dehydroxylace 0,77 a u exotermy vzniku krystalických fází $z$ metakaolinitu 0,73 . V prrípadě korelace krystalinity kaolinitu a pološǐřky studované exotermy dosahovala tato hodnota 0,88 . Z grafu A a B na obrázku 5 je zřejmá přímo úměrná závislost: čím vyšší krystalinita kaolinitu, tím vyšší teplota studovaných fázových přeměn. Graf $C$ na obrázku 5 ukazuje závislost nepř́ímo úměrnou: se zvyšující se krystalinitou klesá pološířka studovaného exotermního efektu. Osm vzorků představuje relativně malé množství pro vyslovení jasného obecně platného závěru. Pro spolehlivější důkaz závislostí je třeba provést experimenty s větší sérií vzorků. Ze závislosti bylo vynecháno vyhodnocení pomocí Scherrerovy rovnice, protože ve výpočtu je zahrnut tvarový faktor (tvar ideální koule), ale krystality jsou výrazně anizotropní. Proto je toto stanovení nepřesné. Bylo vynecháno i stanovení závislostí pomocí Rietveldovy metody, protože vypřesnění difraktogramu z reflexní geometrie není u fylosilikátů vlivem přednostní orientace nikdy dokonalé.

Zjištěným závislostem (obr. 5) se vymyká vzorek DS1, jehož hodnoty byly při konstrukci regresních prŕmek vynechány. Ačkoliv má tento vzorek dle XRD nejvyšší krystalinitu kaolinitu z celého studovaného souboru, teploty fázových transformací se zde pohybovaly v oblasti srovnatelné se vzorky s nižší krystalinitou kaolinitu. Zároveň jsou v oblasti dehydroxylace jílových minerálů na křivce tepelného toku (obr. 4) pozorovatelné dva částečně se překrývající efekty, tzv. dublet. První efekt prŕśsluší dehydroxylaci kaolinitu a druhý efekt s největší pravděpodobností dehydroxylaci illitu. Tato transformace probíhá $\mathrm{v}$ rozmezí teplot cca $450-780{ }^{\circ} \mathrm{C}$ (Húlan et al. 2017). Takto vznikající struktura se označuje jako anhydrid illitu nebo také metaillit (Slaughter, Keller 1959). Jistý podíl na výšeteplotní části pozorovaného dubletu může mít i strukturní přeměna alkalického živce, jehož obsah ve vzorku dosahuje cca $7,5 \mathrm{hm}$. \%. A to i přesto, že teplota dekripitace živců je uváděna při teplotě $800-890^{\circ} \mathrm{C}$ (Feng, Ma 2004). Exotermní efekt vzniku krystalických fází $\mathrm{z}$ metakaolinitu, respektive metaillitu vykazuje podobnou teplotu maxima jako u vzorků KN-83 a ZREF, ale na rozdíl od nich má nízkou výškovou intenzitu a naopak vysokou pološíŕku. Nelze vyloučit, že odlišnost průběhu tohoto děje je zapř́ičiněna relativně vysokým obsahem illitu a alkalického živce ve vzorku DS1. Je tedy možné, že na průběh vysokoteplotních fázových přeměn mají kromě krystalinity vliv i jiné vlastnosti kaolinitu, jako např. defekty krystalové struktury nebo rozdílné minerální a tudíž i chemické složení kaolinů. Pro ověření těchto hypotéz by bylo potřeba provést experimenty $\mathrm{s}$ větším množstvím kaolinů se zvýšeným obsahem alkalických živců a illitu. Vzorek GP3 představuje uměle vytvořenou směs dvou kaolinitů s rozdílnou krystalinitou, která způsobuje př́tomnost dubletu exotermního efektu odpovídajícího vzniku krystalických fází z metakaolinitu.

Bylo provedeno porovnání závislosti průběhu krystalizace mullitu a jeho krystalinity na krystalinitě kaolinitu v surovině. U vzorku s nižší krystalinitou (K) byl pozorován rapidnější nárůst obsahu dobře krystalického mullitu od teploty cca $1200^{\circ} \mathrm{C}$. V souladu s publikací Serrano et al. (1996) bylo zjištěno, že kaolinit 
s nízkou krystalinitou produkuje mullit s krystalinitou vysokou a naopak (Elektronická příloha 3$)$.

Při porovnání snímků ze skenovacího elektronového mikroskopu (Elektronická prŕloha 4) a výsledků stanovení krystalinity, (obr. 2, Elektronická prŕloha 1) je zřejmé, že provést hrubý odhad krystalinity, a tedy i reaktivity, kaolinitu je pomocí této metody obtížné, pravděpodobně nemožné.

Výsledky všech použitých metod výpočtu krystalinity jsou navzájem srovnatelné, na relativní škále velmi dobře korelují. Lze konstatovat, že pro studium a zejména předpovězení chování kaolinitu při výpalu je spolehlivější použití Hinckleyho indexu krystalinity, než výpočet velikosti krystalitů absolutními metodami (Rietveldovou metodou a pomocí Scherrerovy rovnice.

\section{Závěr}

1. U většiny vzorků byla experimentálně prokázána závislost průběhu vysokoteplotních transformací na původní krystalinitě kaolinitu. S narůstající krystalinitou postupně stoupá teplota počátku i maxima efektu dehydroxylace v termogramech. Stejná zá- vislost je pozorovatelná i u exotermické reakce, při které z metakaolinitu krystalizuje tzv. spinelová fáze a mullit.

3. S rostoucí krystalinitou kaolinitu se zmenšuje pološírka (FWHM) exotermního efektu odpovídajícího vzniku krystalických fází z metakaolinitu. Tudíž tato transformace probíhá $\mathrm{v}$ menším teplotním rozmezí.

4. Výsledky experimentů odpovídají teorii, že krystalinita původního kaolinitu má vliv na proces tvorby struktury mullitu. Až na výjimky zřejmě platí, že čím je velikost krystalitů kaolinitu nižší, tím vyšší je krystalinita z něj vypáleného mullitu a naopak.

5. Byly srovnány výsledky výpočtu krystalinity Rietveldovou metodou a pomocí Hinckleyho indexu (relativní metoda). Výsledkem je, že pro předpovězení chování kaolinitu při výpalu je Hinckleyho index spolehlivější.

\section{Poděkování}

Prezentované výsledky vznikly v rámci projektu TAČR Epsilon TH02020321 Výroba mullitových ostřiv v šachtové peci. Autoři děkují recenzentưm a editorovi za cenné prípomínky a diskuzi.

\section{Literatura}

Brindley, G. W., Nakahira, M. (1959a). The Kaolinite-Mullite Reaction Series: I, A Survey of Outstanding Problems. - Journal of the American Ceramic Society, 42, 7, 311-314. https://doi.org/10.1111/j.1151-2916.1959.tb14314.x

Brindley, G. W., Nakahira, M. (1959b). The Kaolinite-Mullite Reaction Series: II, Metakaolin. - Journal of the American Ceramic Society, 42, 7, 314-318. https://doi.org/10.1111/j.1151-2916.1959.tb14315.x

Brindley, G. W., Nakahira, M. (1959c). The Kaolinite-Mullite Reaction Series: III, The High-Temperature Phases. - Journal of the American Ceramic Society, 42, 7, 319-324. https://doi.org/10.1111/j.1151-2916.1959.tb14316.x

Bellotto, M., Gualtieri, A., Artioli, G., Clark, S. M. (1995). Kinetic study of the kaolinite-mullite reaction sequence. Part I: Kaolinite dehydroxylation. - Physics and chemistry of minerals, 22, 4, 207-217. https://doi.org/10.1007/BF00202253

Chakraborty, A. K. (2014). Phase transformation of kaolinite clay. - Springer India. 346 s. https://doi.org/10.1007/978-81-3221154-9

Číčel, B., Novák, I., Horváth, I. (1981). Mineralogy and crystallochemistry of clays. - SAV, Bratislava.

Feng, W., Ma, Hongwen. (2004). Thermodynamic analysis and experiments of thermal decomposition for potassium feldspar at intermediate temperatures. - Journal of the Chinese Ceramic Society, 32, 789-799.

Hinckley, D. N. (1962). Variability in "crystallinity" values among the kaolin deposits of the coastal plain of Georgia and South Carolina. - Clays and clay minerals, 11, 1, 229-235. https://doi.org/10.1346/CCMN.1962.0110122

Húlan, T., Trník, A., Medved, I. (2017). Kinetics of thermal expansion of illite-based ceramics in the dehydroxylation region during heating. - Journal of Thermal Analysis and Calorimetry, 127, 1, 291-298. https://doi.org/10.1007/s10973-016-5873-0

Lee, S., Kim, Y. J., Moon, H. S. (1999). Phase Transformation Sequence from Kaolinite to Mullite Investigated by an Energy-Filtering Transmission Electron Microscope. - Journal of the American Ceramic Society, 82, 10, 2841-2848. https://doi. org/10.1111/j.1151-2916.1999.tb02165.x

Lee, S., Kim, Y. J., Moon, H. S. (2003). Energy-Filtering Transmission Electron Microscopy (EF-TEM) Study of a Modulated Structure in Metakaolinite, Represented by a $14 \AA$ A Modulation. - Journal of the American Ceramic Society, 86, 1, 174-176. https://doi.org/10.1111/j.1151-2916.2003.tb03297.x

Murray, H. H. (2006). Structure and composition of the clay minerals and their physical and chemical properties. - Developments in clay science, $2,7-31$. https://doi.org/10.1016/S1572-4352(06)02002-2

Rietveld, H. (1969). A profile refinement method for nuclear and magnetic structures. - Journal of applied Crystallography, 2, 2 , 65-71. https://doi.org/10.1107/S0021889869006558

Serrano, F. J., Bastida, J., Amigó, J. M., Sanz, A. (1996). XRD line broadening studies on mullite. - Crystal Research and Technology, 31, 8, 1085-1093. https://doi.org/10.1002/crat.2170310818

Scherrer, P. (1918). Göttinger Nachrichten Math - Phys, 2, 98-100.

Slaughter, M., Keller, W. D. (1959). High temperature phases from impure kaolinite. - American Ceramic Society Bulletin, 38, $12,702-703$.

Varga, G. (2007). The structure of kaolinite and metakaolinite. - Építőanyag, 59, 1, 6-9. 
Př́loha 1: Výsledky získané z rtg-difrakčních dat.

Appendix 1: Results obtained from X-ray diffraction data.

Výsledky XRD kvantitativní fázové analýzy studovaných vzorků kaolinů v hm. \%, zaokrouhleno na jedno desetinné číslo.

Results of XRD quantitative phase analysis of studied kaolin samples in wt. \%, rounded to one decimal.

\begin{tabular}{|l|c|c|c|c|c|c|}
\hline & Kaolinit & Illit & Křemen & Anatas & K - živec & Muskovit + Illit \\
\hline $\mathbf{1 8 8 6 2}$ & 94,8 & 0,7 & 1,3 & 3,2 & - & - \\
\hline Al & 82,9 & 11 & 5,3 & 0,8 & - & - \\
\hline DS1 & 76,8 & 5,7 & 9,8 & 0,2 & 7,5 & - \\
\hline GP3 & 96,3 & 0,8 & 2,3 & 0,6 & - & - \\
\hline KE & 81,2 & - & 6,5 & 0,2 & - & 12,2 \\
\hline K & 93,8 & 2,7 & 2,6 & 0,9 & - & - \\
\hline KN-83 & 95,4 & 3,1 & 0,9 & 0,6 & - & - \\
\hline ZREF & 98 & - & 1 & 1 & - & - \\
\hline
\end{tabular}

Stanovení krystalinity kaolinitu čtyřmi použitými metodami.

Determination of kaolinite crystallinity by four methods.

\begin{tabular}{|l|c|c|c|c|}
\hline \multirow{2}{*}{} & \multicolumn{4}{|c|}{ Krystalinita } \\
\cline { 2 - 5 } & Scher. Bez Warr. & Scher. S Warr. & Rietveldova met. & Hinckleyho index \\
\hline 18862 & 31,75 & 27,14 & 29,66 & 0,65 \\
\hline DS1 & 47,64 & 37,8 & 51,07 & 0,96 \\
\hline GP3 & 85,99 & 60,78 & 86,84 & 1,4 \\
\hline KE & 47,24 & 38,06 & 40,62 & 1,03 \\
\hline K & 44,02 & 35,48 & 48,67 & 0,95 \\
\hline KN-83 & 31,84 & 27,27 & 26,63 & 0,75 \\
\hline ZREF & 60,23 & 46,48 & 45,67 & 1,18 \\
\hline
\end{tabular}

Příloha 2: Tabulka hodnot odečtených z termoanalytických křivek, zaokrouhleno na dvě desetinná místa. Appendix 2: Table of values read from thermoanalytic curves, rounded to two decimals.

\begin{tabular}{|c|c|c|c|c|c|c|c|c|c|c|}
\hline & \multirow{2}{*}{$\begin{array}{l}\Delta \text { mcelk. } \\
{[\mathrm{hm} . \%]}\end{array}$} & \multicolumn{5}{|c|}{ dehydroxylace a vznik metakaolinitu } & \multicolumn{4}{|c|}{ vznik tzv. spinelové fáze a mullitu } \\
\hline & & $\begin{array}{c}\Delta \mathrm{m} \\
{[\mathrm{hm} . \%]}\end{array}$ & $\begin{array}{c}\text { onset } \\
{\left[{ }^{\circ} \mathrm{C}\right]}\end{array}$ & $\begin{array}{c}\text { maximum } \\
{\left[{ }^{\circ} \mathrm{C}\right]}\end{array}$ & $\begin{array}{c}\text { offset } \\
{\left[{ }^{\circ} \mathrm{C}\right]}\end{array}$ & $\begin{array}{c}\text { heat } \\
{[\mu \mathrm{V} \cdot \mathrm{s} / \mathrm{mg}]}\end{array}$ & onset $\left[{ }^{\circ} \mathrm{C}\right]$ & $\begin{array}{c}\operatorname{maximum} \\
{\left[{ }^{\circ} \mathrm{C}\right]}\end{array}$ & $\begin{array}{c}\text { offset } \\
{\left[{ }^{\circ} \mathrm{C}\right]}\end{array}$ & $\begin{array}{c}\text { heat } \\
{[\mu \mathrm{V} \cdot \mathrm{s} / \mathrm{mg}]}\end{array}$ \\
\hline $\mathrm{Al}$ & $-12,63$ & $-10,67$ & 471,2 & 537,56 & 610,63 & 121,49 & 981,99 & 993,43 & 1002 & $-14,21$ \\
\hline KE & $-12,35$ & $-10,59$ & 471,72 & 535,06 & 603,89 & 106,34 & 991,07 & 1000,06 & 1006,25 & $-14,44$ \\
\hline 18862 & $-13,87$ & $-11,64$ & 477,36 & 534,87 & 581,82 & 137,8 & 979,17 & 989,13 & 997,95 & $-16,42$ \\
\hline GP3 & $-13,29$ & $-11,78$ & 477,89 & 539,33 & 593,97 & 138,48 & 981,38 & 993,23 & 1007,13 & $-16,68$ \\
\hline $\mathbf{K}$ & $-12,83$ & $-11,15$ & 476,36 & 533,53 & 581,73 & 105,52 & 973,65 & 986,7 & 998,05 & $-13,87$ \\
\hline KN-83 & $-13,87$ & $-12,19$ & 483,57 & 547,91 & 609,2 & 132,05 & 997,58 & 1002,44 & 1005,62 & $-16,92$ \\
\hline ZREF & $-14,56$ & $-12,64$ & 478,18 & 545,87 & 609,09 & 143,97 & 995,13 & 1000,75 & 1004,61 & $-17,97$ \\
\hline DS1 & $-10,65$ & $-9,32$ & 469,36 & 537,12 & 692,83 & 112,78 & 986,16 & 999,87 & 1008,3 & $-12,25$ \\
\hline
\end{tabular}


Příloha 3: Vysokoteplotní rtg-difrakční analýza.

Appendix 3: High-temperature X-ray diffraction analysis.

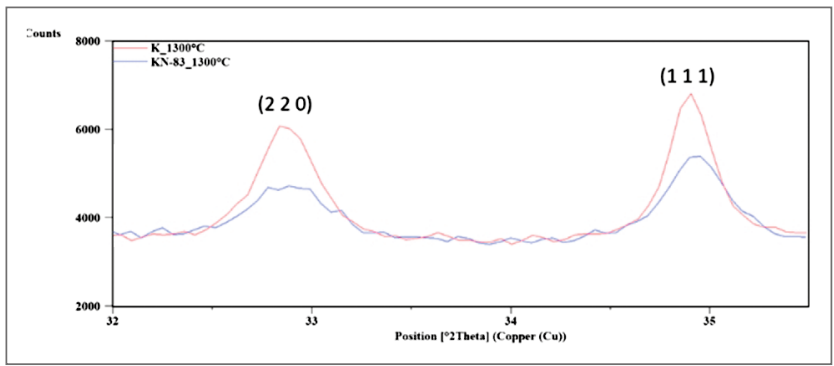

Porovnání krystalinity mullitu vznikajícího ze vzorku K (nízká krystalinita kaolinitu) a vzorku KN-83 (vysoká krystalinita kaolinitu) a základě srovnání profilů difrakčních linií. Analyzováno pomocí in-situ htXRD při teplotě

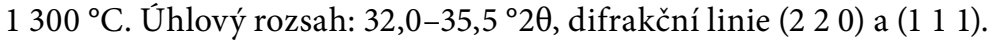

Comparison of mullite crystallinity arising from sample K (low crystallinity of kaolinite) and sample KN-83 (high crystallinity of kaolinite) based on diffraction line profiles. Analyzed by in-situ htXRD at $1300{ }^{\circ} \mathrm{C}$. Angular range: $32.0-35.5^{\circ} 2 \theta$, diffraction lines $\left(\begin{array}{lll}2 & 2 & 0\end{array}\right)$ and $\left(\begin{array}{lll}1 & 1 & 1\end{array}\right)$.

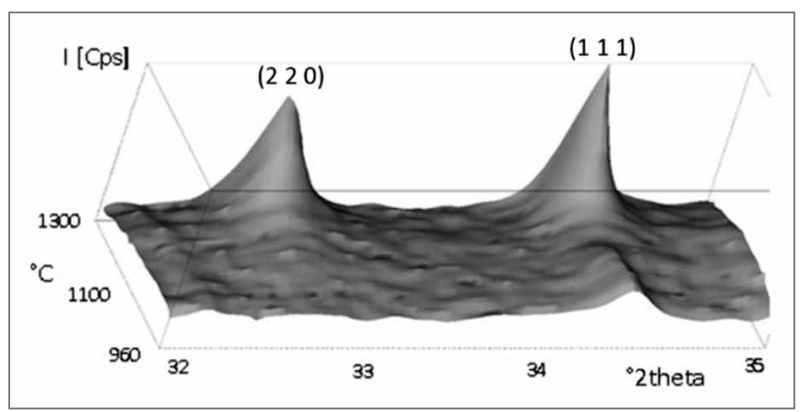

Kaolin K

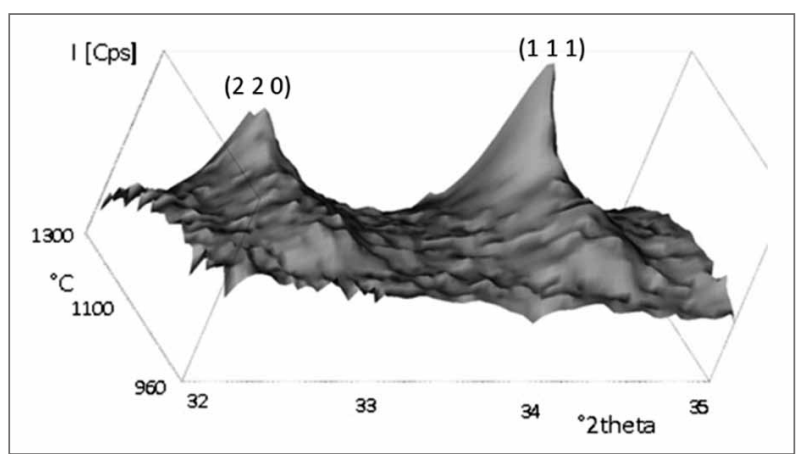

Kaolin KN-83

Porovnání průběhu vysokoteplotních XRD experimentů provedených na vzorcích K a KN-83 v oblasti $960-1300{ }^{\circ} \mathrm{C}$. 3-D záznamy byly získány interpolací.

Comparison of high-temperature XRD experiments performed on samples Kand KN-83 in the region of $960-1300{ }^{\circ} \mathrm{C}$. 3-D images were obtained by interpolation. 
Příloha 4: Snímky ze skenovacího elektronového mikroskopu (SEM). Kaoliny GP3, Al, KE, K a ZREF. Attachment 4: Scanning Electron Microscope (SEM) images. Kaolin GP3, Al, KE, K and ZREF.

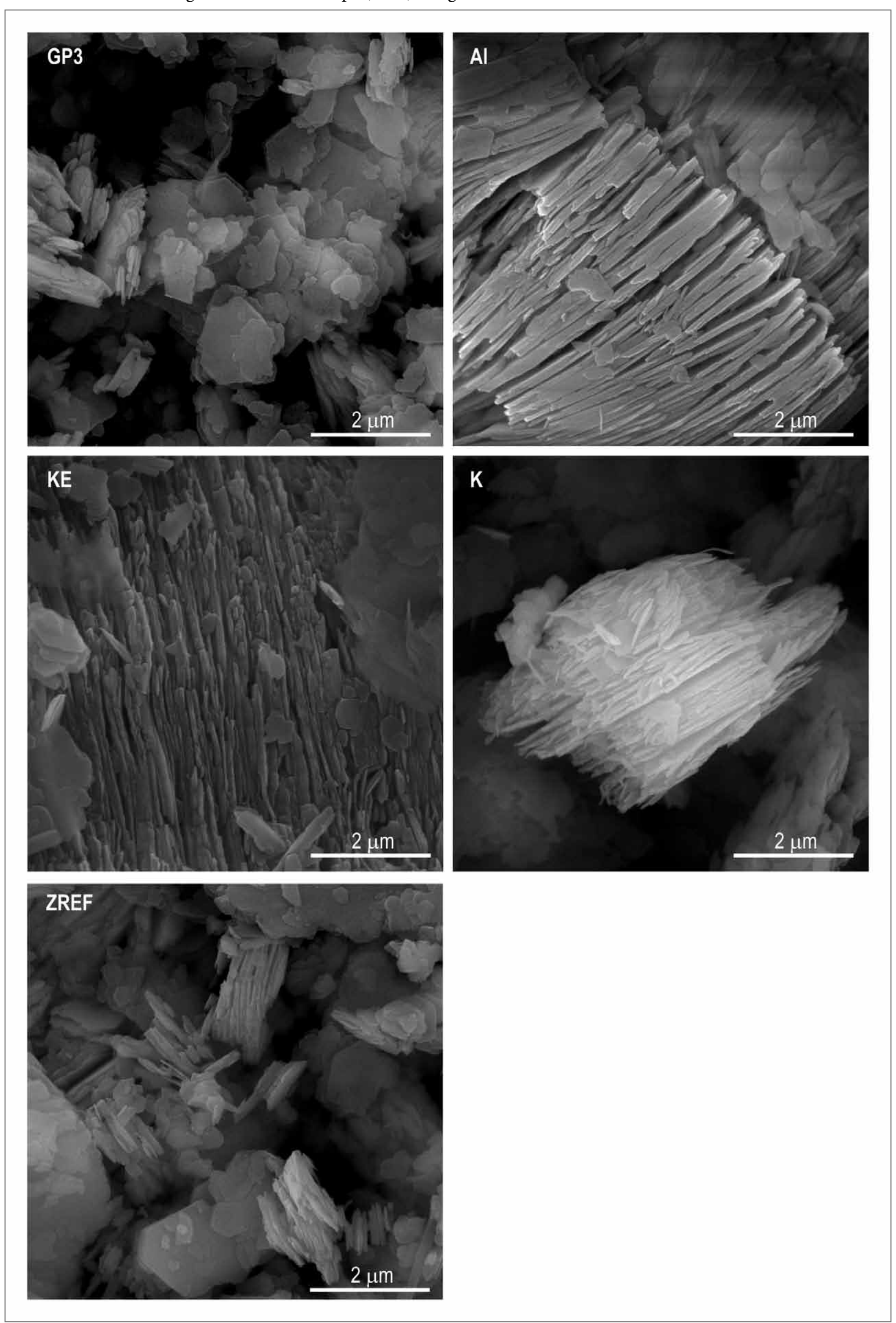

